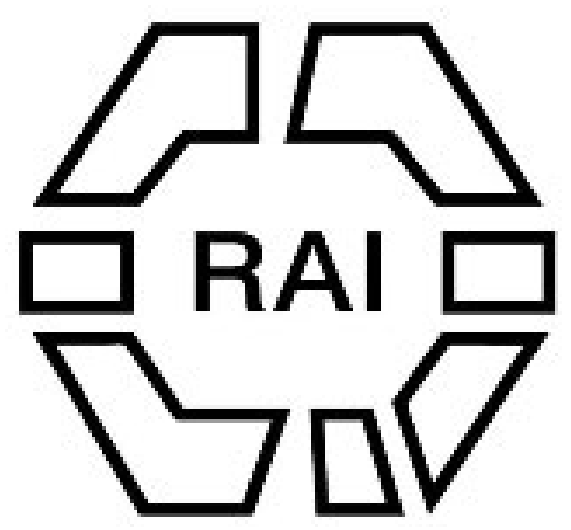

A Colony of Heathens.

Author(s): J. E. M.

Source: The Journal of the Anthropological Institute of Great Britain and Ireland, Vol. 2 (1873), pp. 447-449

Published by: Royal Anthropological Institute of Great Britain and Ireland

Stable URL: http://www.jstor.org/stable/2841469

Accessed: $15 / 06 / 2014$ 18:44

Your use of the JSTOR archive indicates your acceptance of the Terms \& Conditions of Use, available at http://www.jstor.org/page/info/about/policies/terms.jsp

JSTOR is a not-for-profit service that helps scholars, researchers, and students discover, use, and build upon a wide range of content in a trusted digital archive. We use information technology and tools to increase productivity and facilitate new forms of scholarship. For more information about JSTOR, please contact support@jstor.org. 
hieroglyphic characters. I shall, indeed, be surprised to find that those inscriptions have any such antiquity as Mr. Hyde Clarke ascribes to them, seeing that the olo on which he lays so much stress, and several other of the Harnath forms are yet used by a North African race. At least such I judge to be the case from the description of the Tuarick written character, given in the introduction to "Denham and Clapperton's Travels in Northern and Central Africa." Of the eighteen signs there given, it appears to me that at least half may be traced in the Hamath inscriptions, among them being olo (Yigh). It is noticeable that "on almost every stone in places they [the Tuaricks] frequent, the Tuarick characters are hewn out. It matters nothing whether the letters are written from the right to the left, or vice vers $\hat{a}$, or written horizontally." This description answers almost exactly to that of the characters in the Hamath inscriptions, in which, moreover, there appears to be much difference, in the actual formation of the figures employed. Yours obediently,

C. Staniland WaKe.

To the Editor of the Journal of the Anthropological Institute.

\section{A Colony of Heathens.}

Sir,-In spending large sums of money every year in sending missionaries to foreign countries for the conversion of the heathen abroad, we are very apt to forget our own heathen at home. A reiteration of the statement that there are heathens in London would fail to excite any surprise. But when I assert that within twenty-four hours' ride of the "Great City," there are heathens proper-that is, bona fide idol worshippers - it may startle not a few of the pious people who keep on good terms with their conscience by annually sending their mites to some missionary fund for the conversion of the Chickaboo Islanders. I must confess that it is by no means comfortable, after boasting for generations to all the world of our civilisation and Christianity, to suddenly discover that in our very midst is a race of barbarians, who, lacking the knowledge of the true God, fall down and worship a wooden image. But however startling it may be, I assert that it is positively true.

Off the West Coast of Ireland, in lat. $54^{\circ} 8^{\prime}$ N., and long. $10^{\circ} 12$ W., are two islands known as Inishkea, north and south. The word is Irish, and signifies "Inish," an island, "Kea," a thorn bush. So that the name suggests that at some remote period thorn-bushes were found there, though I observed, during my recent visit, that the thorn-bush was conspicuous by its absence. With the exception of one hill called Knocknaskea, the islands are perfectly flat. The islanders are ruled by "a king," who is said to be upwards of a hundred years of age. While having my doubts on this point, I am bound to say that his majesty is particularly hoary, and has certainly passed the allotted three-score years and ten. He is a most agreeable monarch, and is much beloved by his subjects. He has no suite, or palatial residence, and his revenue consists of a small per-centage of 
the fish caught and the potatoes grown. The habitations are mere hollow heaps of stone, plastered over with mud, and thatched with rushes and seaweed. In some of these wretched hovels as many as eight and ten persons herd together, with a goat or pig, and in many cases a cow sharing the accommodation with them.

But this description would not inaptly apply to many other parts of Ireland, and even in some of our agricultural districts the labourers are not much better off in the matter of housing. But here is something that will not apply, it is to be hoped, to any other part of her Majesty's dominions.

The religion of these islanders is confined to the worship of a large wooden idol. This is no exaggerated figure of the Virgin Mary, but a rudely carved image of a man, about eight feet high, dressed in a long flannel gown. I could not ascertain that they have any particular home for the god, and there seemed to be a general desire on the part of the natives to preserve a strict silence with respect to his saintship. It was only after repeated solicitation that I was permitted to visit the place where the idol is kept-a hut, somewhat larger than the surrounding ones, and which is used by the natives as a place of worship. Owing to the situation of the islands they are exposed to the full force of the Atlantic gales, and at such times the inhabitants are unable to pursue their avocation of fishing, and in consequence suffer great privations. The idol is then, amid many lamentations, brought down to the shore, and invoked to still the storm, the natives at the same time prostrating themselves on the sand. Should the gale cease, it is attributed, of course, to the interference of the idol ; but if, on the other hand, no abatement takes place, it is the god's will, and so he is sorrowfully but reverently carried back to his domicile.

These poor people hold very little communication with the outer world, and they have a tradition that they are the descendants of a mighty giant, who with his wife came from a beautiful and fertile island of great extent, which was submerged by the Atlantic. They say that this island was a perfect Paradise; that gorgeous plumaged birds flitted about and made the air melodious with exquisite music, while flowers of the most brilliant hues bloomed perennially. They believe that the enchanted island will some day rise again in all its loveliness, and become the future home of the spirits of their departed friends.

The seals, which abound on the rocky parts of the shore, are regarded with profound veneration, and on no account could a native be induced to kill one, as they are said to be the souls of their departed friends. In the hut of the king is the skin of a large white seal, which I ascertained was piously treasured on account of having formerly been occupied by the soul of a maiden. The following is the legend related to me. Many years ago a beautiful young girl lived upon the island, and was the betrothed of a "dacent boy" by the name of Rooney. One day Rooney and his bride-elect were out fishing in a coracle, when a storm arose and the frail craft was cap- 
sized. The terrified lover endeavoured to save his sweetheart in vain. Before sinking for the last time she bade him farewell, and said she should become a white seal and would sing to him. The brokenhearted Rooney swam ashore, but his reason had fled. For a long time he daily made a pilgrimage round the island in the hope of meeting his departed in the shape of a white seal ; but his journeys were always fruitless. At length, one stormy winter night, when the wind howled across the island with terrific fury, Rooney started from his couch of rushes, and exclairned, "Hark, I hear her singing-she calls me now," and before anyone could stop him, he had bounded off and was lost in the darkness. His friends were about to follow, when they were deterred by a plaintive voice, which in a low musical tone bade them stay. All night long they heard the voice chanting a melancholy lay, but when daylight broke it ceased. Then a search was made, and down on the sea-shore they found the dead body of Rooney with a dead white seal clasped to his breast. The souls of Rooney and his beloved had gone to the enchanted island.

In answer to inquiries I made with respect to the burial of their dead, I was informed that for three days the corpse is allowed to lie with its face exposed, and a light burning at its head. And during this time the wooden god is repeatedly supplicated to give the deceased a safe passage to the Paradisiacal island. At the end of the third day, the friends and relatives assemble at the hut, a procession is formed, and amid much weeping and wailing the remains are carried to the graveyard and there buried, stones from the seashore being piled in heaps to mark the spot.

Some two or three years ago, I believe a missionary went over to Inishkea to attempt the conversion of the heathens ; but, like many of his class who have gone on similar errands to other parts of the world, he commenced his work by scoffing at and reviling the god they worshipped, forgetting that for generations the faith of these poor people had been placed in that senseless image ; and that faith, when once placed, is too strong to be scoffed away. By adopting this course he very naturally failed in his object, and so incensed the natives that he narrowly escaped with his life. Since then nobody seems to have thought it worth while to attempt the conversion of these untutored islanders.

J. E. M.

From the "Echo," Nov. 23, 1872.

\section{Artificialliy EnLarged Ear-lobes.}

THE following supplemental matter has to be added to the paper on "Enlarged Ear-lobes," in the Journal, p. 198.

Among the Cypriote statues recently exhibited in London, two or three of archaic character were found to have plugs of considerable size inserted in the lobes of the ear.

Also, in the copies of the frescoes at Ajunta, now in the India Office, numerous figures are represented with enlarged ear-lobes- 